\title{
Effects of vascular endothelial growth factor and epidermal growth factor on biological properties of gastric cancer cells
}

\author{
Chunfeng Li, Jian Zheng, Yingwei Xue
}

Department of Gastroenterology, The Third Affiliated Hospital of Harbin Medical University, Harbin, China

Submitted: 21 February 2017

Accepted: 5 June 2017

Arch Med Sci 2019; 15 (6): 1498-1509

DOI: https://doi.org/10.5114/aoms.2019.88443

Copyright $\odot 2019$ Termedia \& Banach

\section{Abstract}

Introduction: The exfoliation of exfoliative cells from gastric serosa into the peritoneum is the main cause of peritoneal metastasis, which is the most common form of postoperative recurrence in gastric cancer. This study investigates the effects of vascular endothelial growth factor (VEGF) and epidermal growth factor (EGF) on the biological properties of gastric cancer cells. Material and methods: mRNA expression of VEGF and EGF in gastric cancer tissues from 80 patients suffering from serosa-infiltrated gastric cancer $\left(\mathrm{T}_{3}\right)$ was examined. The differences of proliferation, movement, adhesion and invasion among 4 gastric cancer cell lines were analysed. The mRNA expression of EGF, EGFR, VEGF and VEGFR in the gastric cancer cell lines was examined before and after adding endostatin (Endostar) or cetuximab (Erbitux) to observe changes of gastric cancer cells.

Results: mRNA levels of EGF and VEGF in positive exfoliative cytology cases were significantly higher than negative cases $(p<0.05)$. The biological properties were reduced sequentially in MGC803, HGC27, BGC823 and SGC7901 $(p<0.05)$. The mRNA expression of EGF, EGFR, VEGF and VEGFR was the strongest in $\mathrm{MGC803}$, but was attenuated significantly after treatment $(p<0.05)$.

Conclusions: Lower survival was related to positive exfoliative cytology, lymphatic node metastasis, serosa-infiltrated and poorly differentiated gastric cancer. The expression of VEGF and EGF was correlated with the properties of gastric cancer cells. Specific inhibition of VEGF and EGF may impair the biological properties of gastric cancer cells in vitro.

Key words: exfoliative, expression, gastric cancer, growth factor.

\section{Introduction}

Invasion and metastasis of tumour are mainly responsible for poor prognosis of cancer patients. Peritoneal metastasis accounts for about $50 \%$ of postoperative recurrence in gastric cancer. The exfoliation of exfoliative cells from gastric serosa into the peritoneum is the main cause of peritoneal metastasis. It has been reported that the positive rate of exfoliative cells in serosa infiltrated gastric cancer $\left(T_{3}\right)$ was only about $50 \%$, but the majority of infiltrated gastric cancer were without exfoliative cells [1-4]. The differential expression levels of multiple genes and cytokines may account for the differences of gastric cancer cells in biological properties.

\author{
Corresponding author: \\ Yingwei Xue MD \\ Department \\ of Gastroenterology \\ The Third Affiliated \\ Hospital of Harbin \\ Medical University \\ 150 Haping Road \\ Nangang District \\ 150081 Harbin, China \\ Phone: +86 18745787187 \\ E-mail: yingweixue@gmail. \\ com
}


Previous studies have shown that the expression of vascular endothelial growth factor (VEGF) and epidermal growth factor (EGF) was correlated with growth, invasion and metastasis of gastric cancer, and increased ability of invasion and metastasis facilitated the growth and seeding of exfoliative cells in the peritoneum [5-10]. The differences in the expression of VEGF and EGF between positive and negative exfoliative cell gastric cancer tissues were investigated in order to study the exfoliative cells in the abdominal cavity that are related to peritoneal seeding in gastric cancer. The relationships between the ability of proliferation, migration, invasion and adhesion, and mRNA levels of EGF, VEGF and their respective receptors in four gastric cancer cells were examined. The effects of endostatin (Endostar) or cetuximab (Erbitux) blocking VEGF and EGF signalling pathways on the growth, migration, adhesion and invasion of a gastric cancer cell line with the highest level of EGF, VEGF and their respective receptors were also studied.

\section{Material and methods}

\section{Patients and gastric cancer cell lines}

Eighty patients with serosa-infiltrated gastric cancer were operated on at the Gastrointestinal Department. None of the patients had received radiotherapy, chemotherapy or immunotherapy. They were pathologically diagnosed as adenocarcinoma. Sixty-four cases had distal-end gastric cancer and the others had proximal-end gastric cancer. Patients consisted of 44 males and $36 \mathrm{fe}-$ males aged from 30 to 81 years (mean age: 58 years). Informed consent was obtained from all the patients. Ethic approval was obtained from the Medical Ethics Committee. According to the results of irrigation of the peritoneal cavity, the patients were categorized into two groups: exfoliative cytology positive and negative groups.

Gastric cancer cell lines BGC823 (poorly differentiated gastric adenocarcinoma), MGC803 (poorly differentiated gastric adenocarcinoma), HGC27 (undifferentiated gastric adenocarcinoma) and SGC7901 (moderately differentiated gastric adenocarcinoma) were provided by the Cancer Research Institute, Harbin Medical University. The cell lines were cultured in RPMI-1640 medium containing 10\% foetal bovine serum (FBS), $100 \mathrm{U} / \mathrm{ml}$ Penicillium and $100 \mathrm{U} / \mathrm{ml}$ Streptomycin and 0.25\% Parenzyme (GIBCO, USA), at $37^{\circ} \mathrm{C}$, in $5 \% \mathrm{CO}_{2}$, and $95 \%$ air.

\section{Sample collection and exfoliative cytology analysis}

Before intraperitoneal operation, the gastric bed, spleen fossa and pelvic cavity were washed with 1 I of physiologic saline at $37^{\circ} \mathrm{C}$ and were vacuumed out after gentle churning. The collected washing solution was centrifuged at $2000 \mathrm{rpm}$ at $4^{\circ} \mathrm{C}$ for $10 \mathrm{~min}$. The precipitate was resuspended with $1 \mathrm{ml}$ of diethylpyrocarbonate water for $10 \mathrm{~min}$ before centrifugation at $2000 \mathrm{rpm}$ for $3 \mathrm{~min}$. After removing the supernatant which contained akaryocyte and peritoneal mesothelial cells, the precipitate was used for smear preparation for haematoxylin and eosin staining and CK18 immunohistochemical staining (Zymed, USA). The false positive and the false negative rates were examined by peritoneal lavage cytology and CK18 examination. The remains were defined as intra-abdominal exfoliative cells positive.

\section{Survival rate and clinicopathological parameters}

The survival rates were compared under clinicopathological parameters including exfoliative cytology, lymphatic node metastasis, infiltration of serosa and differentiation.

\section{mRNA expression of EGF, EGFR, VEGF and VEGFR}

Total RNA was extracted using Trizol (GIBCO, USA) from samples collected from patients or gastric cancer cell lines according to the protocol provided by the manufacturer. The extracted RNA was reverse-transcribed into cDNA using an RT-PCR kit (TaKaRa RNA PCR Kit (AMV) ver. 3.0, TaKaRa, Japan). Briefly, the reverse transcription (RT) reaction mixture contained $2 \mu \mathrm{l}$ of $\mathrm{MgCl}_{2}, 1 \mu \mathrm{l}$ of $10 \times \mathrm{RT}$ buffer, $3.75 \mu \mathrm{l}$ of RNase free $\mathrm{dH}_{2} \mathrm{O}, 1 \mu \mathrm{l}$ of dNTP (10 mM each), $0.25 \mu$ of RNase inhibitor, $0.5 \mu \mathrm{l}$ of avian myeloblastosis virus (AMV) reverse transcriptase, $0.5 \mu \mathrm{l}$ of random 9-mers and a $1 \mu \mathrm{l}$ sample RNA in a $10 \mu \mathrm{l}$ final reaction volume. RT was performed in the following conditions: $30^{\circ} \mathrm{C}$ for $10 \mathrm{~min}$, $42^{\circ} \mathrm{C}$ for $30 \mathrm{~min}, 99^{\circ} \mathrm{C}$ for $5 \mathrm{~min}, 5^{\circ} \mathrm{C}$ for $5 \mathrm{~min}$ and at $-20^{\circ} \mathrm{C}$ for storage. The PCR mixture contained $20 \mathrm{ng}$ each of primer, $2.5 \mu \mathrm{l}$ of $10 \times$ PCR buffer, $0.4 \mu \mathrm{l}$ of dNTPs (10 mM each), $0.1 \mu$ l of Taq polymerase and $40 \mu \mathrm{g}$ of cDNA in a $25 \mu \mathrm{l}$ final reaction volume. PCR was performed in a GeneAmp PCR system 9700 (Applied Biosystems, CA) with $94^{\circ} \mathrm{C}$ (1 cycle) for $2 \mathrm{~min}$ and $94^{\circ} \mathrm{C}$ for $30 \mathrm{~s}, 58^{\circ} \mathrm{C}$ for $30 \mathrm{~s}$ and $72^{\circ} \mathrm{C}$ for $1 \mathrm{~min}$ (30 cycles), with $\beta$-actin as the reference gene. The band density was quantified using Image J 1.38 software from the National Institute of Health.

\section{MTT assay}

Cell viability was assessed by the uptake of MTT (thiazolyl blue tetrazolium bromide; Sigma Chemical). Briefly, $6 \times 10^{3}$ gastric cancer cells in RPMI1640 medium with $10 \%$ FBS were plated into 96well plates. At 12, 24, 48, 72 or $96 \mathrm{~h}$, the culture medium in each well was substituted with $200 \mu \mathrm{l}$ 
of fresh medium containing MTT (final concentration, $250 \mu \mathrm{g} / \mathrm{ml}$ ). Plates were then incubated for an additional $4 \mathrm{~h}$ period at $37^{\circ} \mathrm{C}$. Subsequently, the medium was carefully removed with no disturbance to loosely adherent cells. Cells containing the trapped MTT crystals were then solubilized in $100 \mu$ l of dimethyl sulfoxide (DMSO) and vortexed for 10 min to dissolve the crystal thoroughly. Absorbance was determined in a microtitre plate reader (Molecular Devices, Menlo Park, CA) at $570 \mathrm{~nm}$. MTT is a yellow-coloured dye. Living cells in the mitochondrial succinate dehydrogenase can metabolize MTT by the action of isopropyl alcohol particles. In the usual case, the amount of production is proportional to the number of viable cells, so the number of living cells can be deduced from the OD value of $570 \mathrm{~nm}$.

\section{Wound healing assay}

Wound healing assay was used to detect the alteration of cell motility. Gastric cancer cells were seeded onto $35-\mathrm{mm}$ plates at a density of $2 \times 10^{6}$ cells. When cells spread all over the plate, cells were cultured in serum-free medium for $24 \mathrm{~h}$. Cells in half of the plate were erased using cell slicker. Photomicrograph was taken immediately (time $0 \mathrm{~h}$ ), so that the migrated cells could be observed and microphotographed at 12, 24, 36 and $48 \mathrm{~h}$. The experiment was performed in triplicate in each assay and was repeated four times.

\section{Cell adhesion assay}

Cell attachment to matrix (Matrigel) was carried out. Briefly, $8 \mathrm{~g}$ of Matrigel was coated to 96 well plates and incubated at $37^{\circ} \mathrm{C}$ for $1 \mathrm{~h}, 4 \times 10^{5}$ cancer cells were plated in Matrigel-coated plates in triplicate. After incubation at $37^{\circ} \mathrm{C}$ in $5 \% \mathrm{CO}_{2}$ for $2 \mathrm{~h}$, culture media were removed, followed by two washes with phosphate buffered saline. Cells remaining attached to the plate were analysed using MTT assay: \% cells, attached = OD (attached cells)/OD (plated cells) $\times 100 \%$.

\section{Cell invasion assay}

Invasion of gastric cancer cells was analysed using transwell culture chambers (SIGMA, Germany). Polycarbonate microporous membrane facies interna of transwell chambers was coated with $5 \mu \mathrm{g}(10 \mu \mathrm{l})$ of Matrigel (SIGMA, Germany). Briefly, $5 \times 10^{4}$ gastric cancer cells were added to coated membranes in $100 \mu \mathrm{l}$ of serum-free RPMI 1640 medium containing $0.1 \%$ BSA in triplicate wells. $500 \mu \mathrm{l}$ of RPMI 1640 with 5\% FBS medium were placed in a lower chamber and incubated for $24 \mathrm{~h}$. After $24 \mathrm{~h}$ at the end of the experiment, the chambers were washed twice with $0.9 \% \mathrm{NaCl}$ and submerged in 24-well plates in 10\% FBS medium, then incubated at $37^{\circ} \mathrm{C}$ for $4 \mathrm{~h}$ in $5 \% \mathrm{CO}_{2}$. The transwell was taken out and the filter membrane was fixed with methanol for $1 \mathrm{~min}$. The cells that had not penetrated the membrane were erased with cotton swab. The cells were stained in haematoxylin for $3 \mathrm{~min}$, then in eosin for $10 \mathrm{~s}$. The invasive cells were counted under a microscope (400x). All invasion assays were done in triplicate in three independent experiments to ensure consistency. Representative fields were photographed.

\section{Effect of Endostar or Erbitux}

The expressions of EGF, EGFR, VEGF and VEGFR in MGC803 cells were evaluated using semi-quantitative PCR. The MGC803 cells were treated with $1.75 \mathrm{mg} / \mathrm{ml}$ Endostar (Endostatin, Simcere-Medgenn BioPharmaceutical Co., Ltd, Shandong, China) or 162 mg/ml Erbitux (Cetuximab, Merck-China, Beijing, China) for $12 \mathrm{~h}$. The drug concentration is calculated according to this formula:

Peak plasma
$\begin{aligned} & \text { Concentration } \\ & (\mathrm{PPC})[\mu \mathrm{g} / \mathrm{ml}]\end{aligned}$$\quad \frac{\begin{array}{c}\text { Maximum plasma concentra- } \\ \text { tion } / \mathrm{M} 2 \times \text { Average body surface } \\ \text { area } \times 100\end{array}}{\text { Average weight } \times 70}$

Erbitux (Cetuximab, Merck-China, Beijing, China) for $12 \mathrm{~h}$ was evaluated using semi-quantitative PCR. To test the effect of $1.75 \mu \mathrm{g} / \mathrm{ml}$ Endostar or $162 \mu \mathrm{g} / \mathrm{ml}$ Erbitux on the proliferation of MGC803 cells, MGC803 cells $\left(6 \times 10^{3} /\right.$ well $)$ were plated in a $96-$-well plate, followed by $4 \mathrm{~h}$ incubation at $37^{\circ} \mathrm{C}$. Then, $1.75 \mu \mathrm{g} / \mathrm{ml}$ Endostar or $162 \mu \mathrm{g} / \mathrm{ml}$ Erbitux in $0.9 \% \mathrm{NaCl}$ was added to MGC803 cells, with $0.9 \%$ $\mathrm{NaCl}$ as a negative control and oxaliplatin as a positive control. The proliferation was evaluated using MTT assay. To measure the effect of Endostar or Erbitux on the ability of migration, adhesion and invasion, MGC803 cells were plated into a culture flask, followed by $24 \mathrm{~h}$ incubation. Then, $1.75 \mu \mathrm{g} /$ $\mathrm{ml}$ Endostar or $162 \mu \mathrm{g} / \mathrm{ml}$ Erbitux in $0.9 \% \mathrm{NaCl}$ was added to culture medium for 12 with $0.9 \%$ $\mathrm{NaCl}$ as a control. The attached cells were used for migration, adhesion and invasion assays.

\section{Statistical analysis}

Data are presented as means \pm SD. Statistical comparisons were performed using a one-way ANOVA, with $p<0.05$ being considered significant.

\section{Results}

\section{Survival rate and clinicopathological parameters}

Tables I and II show the clinical characteristics of the patients. The survival rate of exfoliative cy- 
tology positive cases is lower than negative cases $(p<0.01)$. Lower survival is related to lymphatic node metastasis, serosa-infiltrated and poorly differentiated gastric cancer $(p<0.01)$ (Figures 1 $\mathrm{C}-\mathrm{F})$.

\section{mRNA levels of EGF and VEGF in gastric cancer tissues}

The mRNA expression of EGF and VEGF was detected in gastric cancer tissues from 80 cases. Among of them, 57 cases are cytology positive and 23 cases are cytology negative. mRNA levels of EGF and VEGF in gastric cancer tissues from the cytology positive group were 1.5 -fold and 2-fold higher, respectively, compared with the cytology negative group (Figures $1 \mathrm{~A}, \mathrm{~B}$ ).

Proliferation, migration, adhesion and invasion ability of gastric cancer cells

The ability of proliferation, migration, adhesion and invasion was assessed in four gastric cancer cell lines: BGC823 (poorly differentiated

Table I. Correlation of expressions of EGF in gastric cancers tissues with serosa invasion $\left(T_{3}\right)$ with clinicopathological parameters

\begin{tabular}{|c|c|c|c|c|c|}
\hline \multirow[t]{2}{*}{ Clinicopathological parameters } & \multirow[t]{2}{*}{$N$} & \multicolumn{2}{|c|}{ EGF } & \multirow[t]{2}{*}{$\chi^{2}$} & \multirow[t]{2}{*}{$P$-value } \\
\hline & & + & - & & \\
\hline Free cancer cell: & & & & 15.956 & $<0.001$ \\
\hline Positive & 57 & 38 & 19 & & \\
\hline Negative & 23 & 4 & 19 & & \\
\hline Gender: & & & & 5.268 & 0.022 \\
\hline Male & 44 & 18 & 26 & & \\
\hline Female & 36 & 24 & 12 & & \\
\hline Tumour size $\left[\mathrm{cm}^{2}\right]$ : & & & & 10.008 & 0.007 \\
\hline$<20$ & 38 & 13 & 25 & & \\
\hline $20-40$ & 23 & 15 & 8 & & \\
\hline$>40$ & 19 & 14 & 5 & & \\
\hline Lauren type: & & & & 0.343 & NS \\
\hline Intestinal type & 31 & 15 & 16 & & \\
\hline Diffuse type & 49 & 27 & 22 & & \\
\hline Borrmann type: & & & & 3.275 & NS \\
\hline$I+I I$ & 60 & 28 & 32 & & \\
\hline $\mathrm{III}+\mathrm{IV}$ & 20 & 14 & 6 & & \\
\hline Growth pattern: & & & & 9.625 & 0.002 \\
\hline Expansive & 34 & 11 & 23 & & \\
\hline Infiltrative & 46 & 31 & 15 & & \\
\hline Differentiation: & & & & 5.647 & 0.017 \\
\hline Poorly differentiated, undifferentiated & 28 & 22 & 6 & & \\
\hline High-moderately differentiated & 52 & 20 & 32 & & \\
\hline Lymph node metastasis: & & & & 6.741 & NS \\
\hline NO & 16 & 5 & 11 & & \\
\hline N1 & 17 & 12 & 5 & & \\
\hline N2 & 32 & 15 & 17 & & \\
\hline N3 & 15 & 10 & 5 & & \\
\hline
\end{tabular}


gastric adenocarcinoma), MGC803 (poorly differentiated gastric adenocarcinoma), HGC27 (undifferentiated gastric adenocarcinoma) and SGC7901 (moderately differentiated gastric adenocarcinoma). The growth rate of $\mathrm{MGC} 803$, HGC27, BGC823 and SGC7901 slowed down sequentially (Figure $2 \mathrm{~A}$ ). The wound healing assay was carried out to test the migration ability of four gastric cancer cell lines. MGC803 showed the strongest migration ability and the migrated MGC803 cells to scraping wound was 2-3-fold higher than the migrated SGC7901 cells (Fig- ure $2 \mathrm{~B})$. The adhesion assay showed that more MGC803 cells were attached to the Matrigel than HGC27, BGC823 and SGC7901 (MGC803 vs. HGC27, BGC823 or SGC7901, $50.65 \pm 5.63$ vs. $44.6 \pm 3.98,36.22 \pm 5.10$ or $30.83 \pm 6.64$ ) (Figure 3 A). MGC803 showed the strongest ability of invasion to the matrix and invasion of MGC803 cells through Matrigel, which were 4-fold more numerous than the invaded SGC7901 cells (Figure $3 \mathrm{~B}$ ). This suggests that MGC803 cells possess more invasive properties compared with HGC27, BGC823 and SGC7901.

Table II. Correlation of expression of VEGF in gastric cancer tissues with serosa invasion $\left(T_{3}\right)$ with clinicopathological parameters

\begin{tabular}{|c|c|c|c|c|c|}
\hline \multirow[t]{2}{*}{ Clinicopathological parameters } & \multirow[t]{2}{*}{$N$} & \multicolumn{2}{|c|}{ VEGF } & \multirow[t]{2}{*}{$\chi^{2}$} & \multirow[t]{2}{*}{$P$-value } \\
\hline & & + & - & & \\
\hline Free cancer cell: & & & & 7.871 & 0.005 \\
\hline Positive & 57 & 37 & 20 & & \\
\hline Negative & 23 & 7 & 16 & & \\
\hline Gender: & & & & 3.600 & NS \\
\hline Male & 44 & 20 & 24 & & \\
\hline Female & 36 & 24 & 12 & & \\
\hline Tumour size $\left[\mathrm{cm}^{2}\right]$ : & & & & 3.648 & NS \\
\hline$<20$ & 38 & 18 & 20 & & \\
\hline $20-40$ & 23 & 12 & 11 & & \\
\hline$>40$ & 19 & 14 & 5 & & \\
\hline Lauren type: & & & & 0.001 & NS \\
\hline Intestinal type & 31 & 17 & 14 & & \\
\hline Diffuse type & 49 & 27 & 22 & & \\
\hline Borrmann type: & & & & 4.310 & 0.038 \\
\hline$I+\|$ & 60 & 29 & 31 & & \\
\hline$I I I+I V$ & 20 & 15 & 5 & & \\
\hline Growth pattern: & & & & 6.715 & 0.010 \\
\hline Infiltrative & 34 & 13 & 21 & & \\
\hline Expansive & 46 & 31 & 15 & & \\
\hline Differentiation: & & & & 9.670 & 0.020 \\
\hline Poorly differentiated & 28 & 22 & 6 & & \\
\hline High-moderately differentiated & 52 & 22 & 30 & & \\
\hline Lymph node metastasis: & & & & 12.021 & 0.007 \\
\hline NO & 16 & 3 & 13 & & \\
\hline N1 & 17 & 9 & 8 & & \\
\hline N2 & 32 & 21 & 11 & & \\
\hline N3 & 15 & 11 & 4 & & \\
\hline
\end{tabular}


A

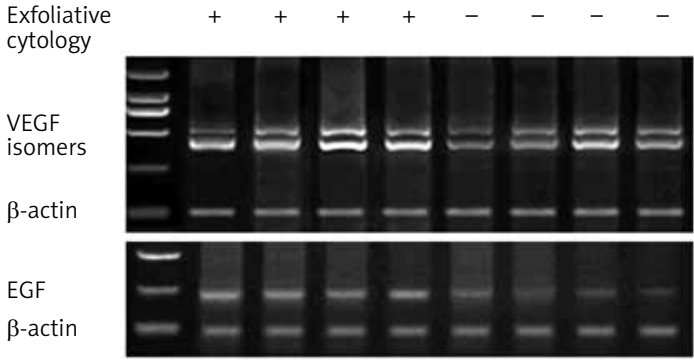

C

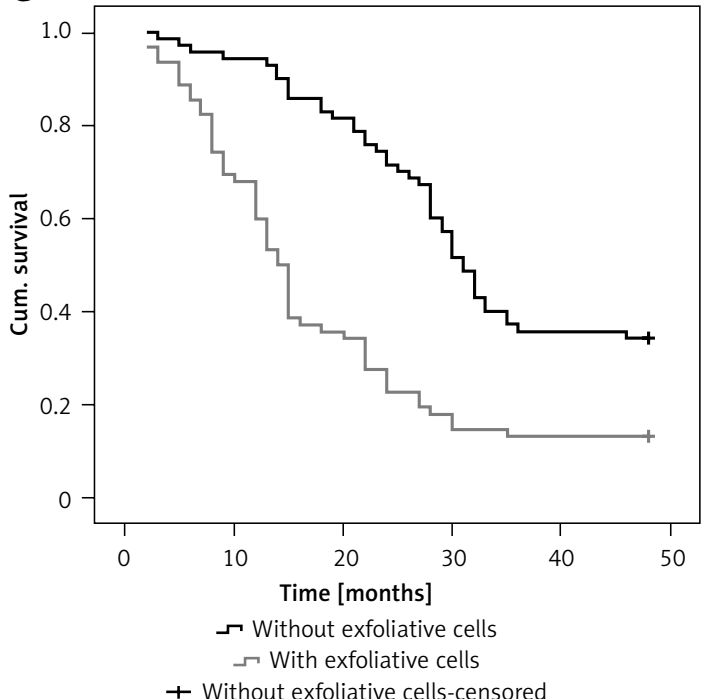

+ Without exfoliative cells-censored

+ With exfoliative cells-censored

$E$

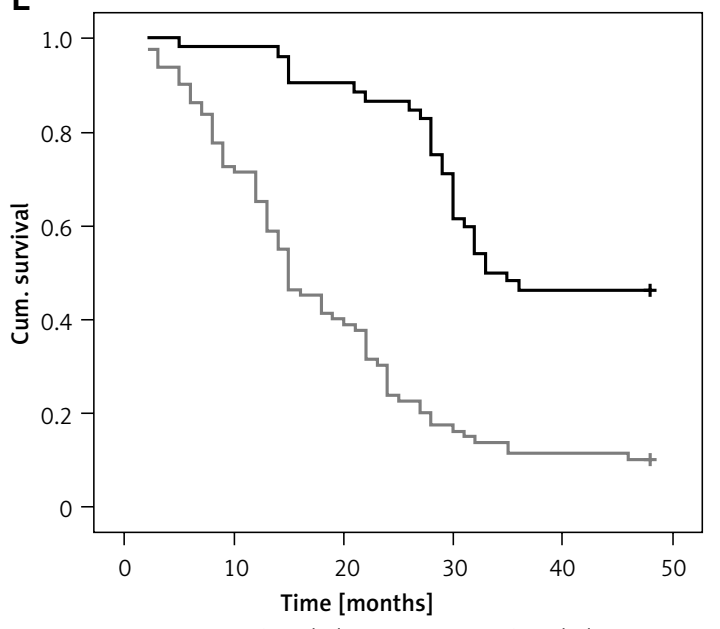

$\neg$ Serosa uninvaded $\rightarrow$ Serosa invaded

+ Serosa uninvaded-censored

+ Serosa invaded-censred
B

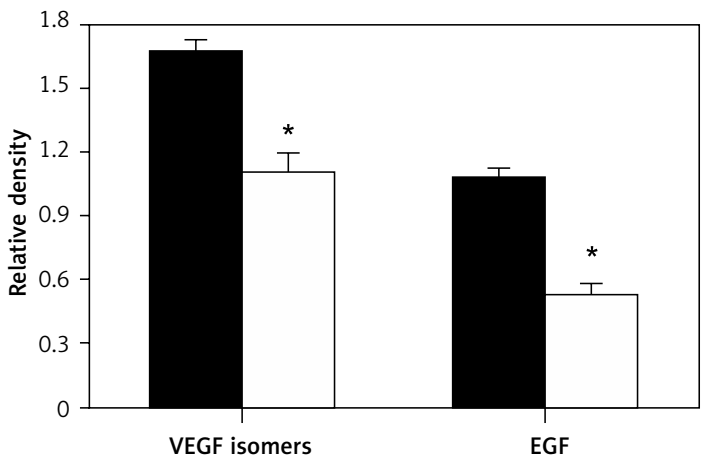

Exfoliative cytology positive $\square$ Exfoliative cytology negative

D

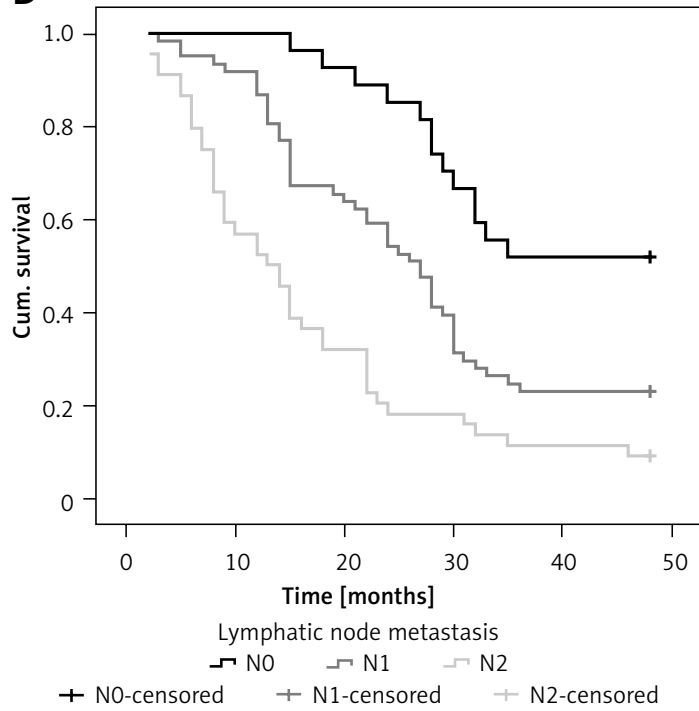

$\mathrm{F}$

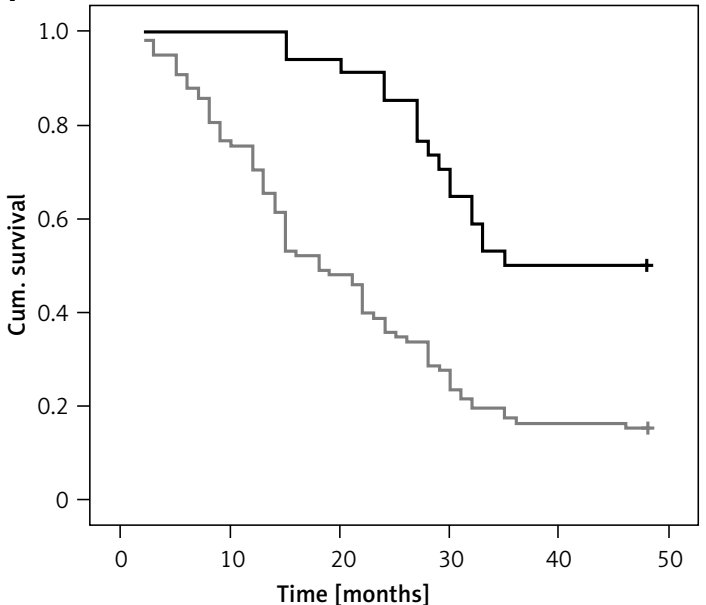

$\neg$ Poorly differentiated $\lrcorner$ High-moderately differentiated + Poorly differentiated-censored + High-moderately differentiated-censored

Figure 1. mRNA expression of VEGF and EGF in cancer tissues and survival curves. A - mRNA levels of VEGF and EGF in cancer tissues from the patients with positive exfoliative cytology or negative exfoliative cytology. B - The quantification of band density (mean \pm SD). mRNA levels of VEGF and EGF were normalized to the $\beta$-actin mRNA level. ${ }^{\star} P<0.05$. $C$ - Survival curves of exfoliative cytology positive cases and negative cases. $\mathbf{D}$ - Survival curves of different lymphatic node metastasis cases. E - Survival curves with serosa-infiltrated cases and without serosa-infiltrated cases. F - Survival curves of poorly differentiated, well-moderately differentiated gastric cancer 


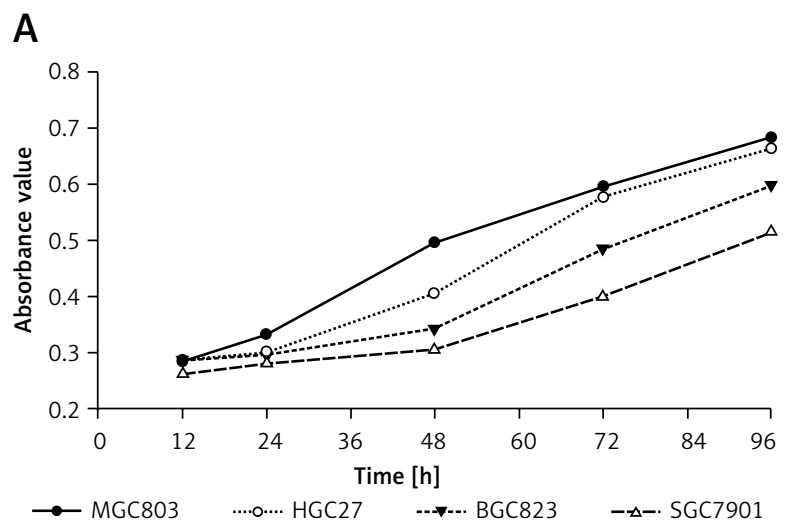

B
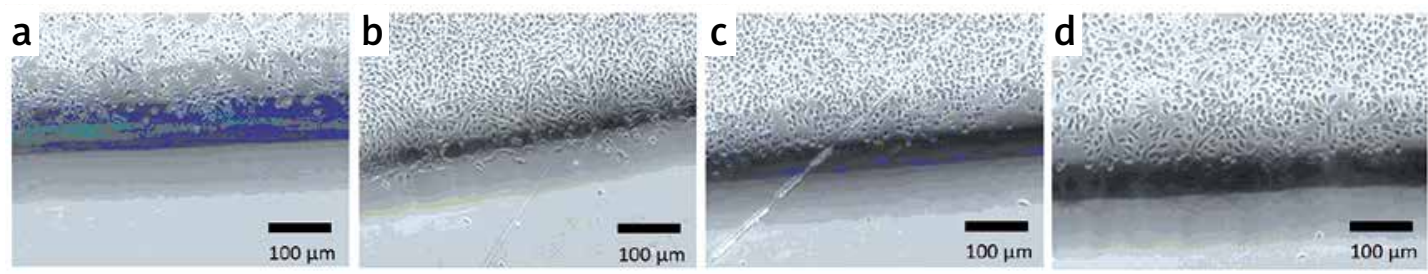

e

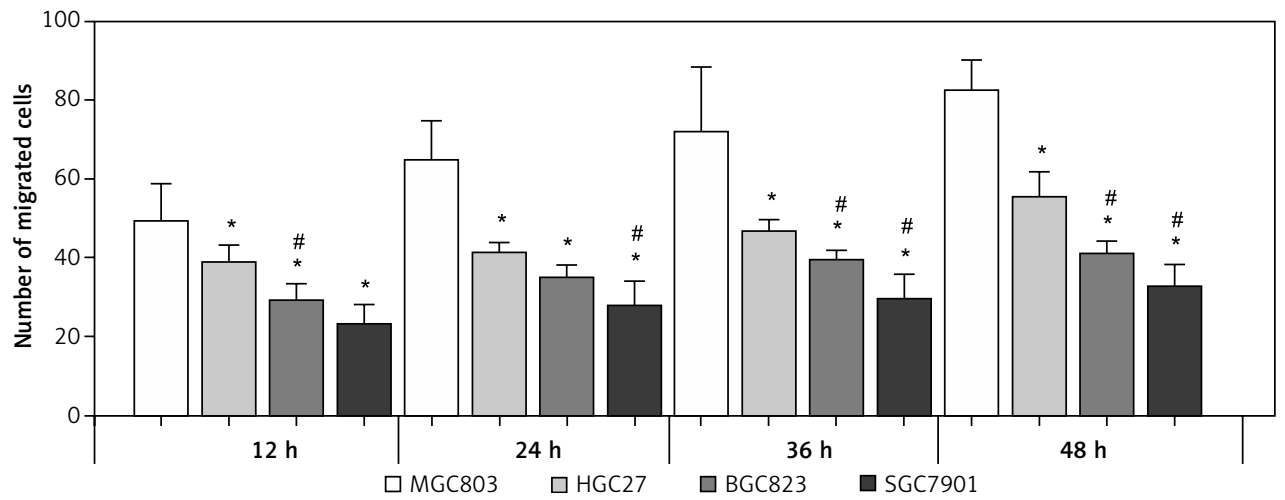

Figure 2. Growth and migration ability of cancer cell lines. A - Growth curve of MGC803, HGC27, BGC823 and SGC7901. B - Representative micrograph of wound healing from MGC803 (a), HGC27 (b), BGC823 (c) and SGC7901 (d) at $36 \mathrm{~h}(\mathrm{e})$. Numbers of migrated cells were quantified at $12 \mathrm{~h}, 24 \mathrm{~h}, 36 \mathrm{~h}$ and $48 \mathrm{~h}$ (mean \pm SD)

${ }^{\star} p<0.05$ compared with MGC803 at the same time point, ${ }^{*} p<0.05$ compared with HGC27 at the same time point.

mRNA levels of EGF, EGFR, VEGF and VEGFR in gastric cancer cell lines

To examine the role of EGF and VEGF in advanced cancer, mRNA levels of EGF, EGFR, VEGF and VEGFR were examined in four gastric cancer cell lines. The results showed that VEGF, EGF, EGFR, VEGFR1 and VEGFR2 mRNA were expressed more highly in the MGC803 compared with the rest of the gastric cancer cell lines. The mRNA levels of VEGF, EGF, EGFR, VEGFR1 and VEGFR2 in MGC803 cells were $2-5$-fold higher than the SGC7901 cells (Figure $4 \mathrm{~A}$ ).

Inhibition of proliferation, migration, adhesion and invasion ability

MGC803 cells were treated with $1.75 \mu \mathrm{g} / \mathrm{ml}$ Endostar or $162 \mu \mathrm{g} / \mathrm{ml}$ Erbitux for $12 \mathrm{~h}$ to assess the effect of Endostar and Erbitux on the mRNA expression of VEGF, EGFR1, EGFR2, EGF, and EGFR. The results showed that Endostar decreased the VEGF, EGFR1 and EGFR2 mRNA levels in MGC803 cells by $39 \%, 25 \%$ and $78 \%$, respectively. Erbitux decreased EGF, EGFR and VEGF mRNA levels by $40 \%, 67 \%$ and $64 \%$, respectively. These data suggested that Endostar and Erbitux interrupted VEGF and EGF signals by decreasing the mRNA levels of EGF, VEGF and their receptors.

To further assess the role of EGF and VEGF in the proliferation, migration, adhesion and invasion ability, MGC803 cells were treated with $1.75 \mu \mathrm{g} /$ $\mathrm{ml}$ Endostar or $162 \mu \mathrm{g} / \mathrm{ml}$ Erbitux (Figures $4 \mathrm{~B}, \mathrm{C}$ ). Both Endostar and Erbitux decreased the growth of MGC803 (Figure 5 A). After Endostar or Erbitux treatment (12, 24, 36 and $48 \mathrm{~h}$ ), the migrated MGC803 cells to the scraping wound were de- 
A
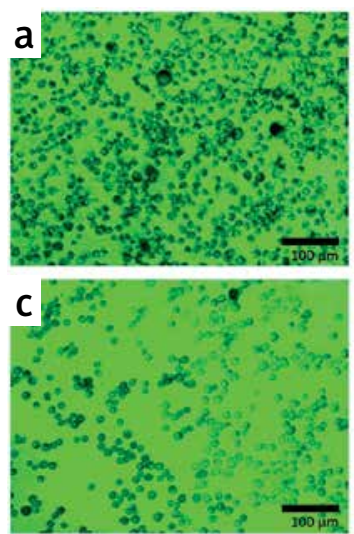

C
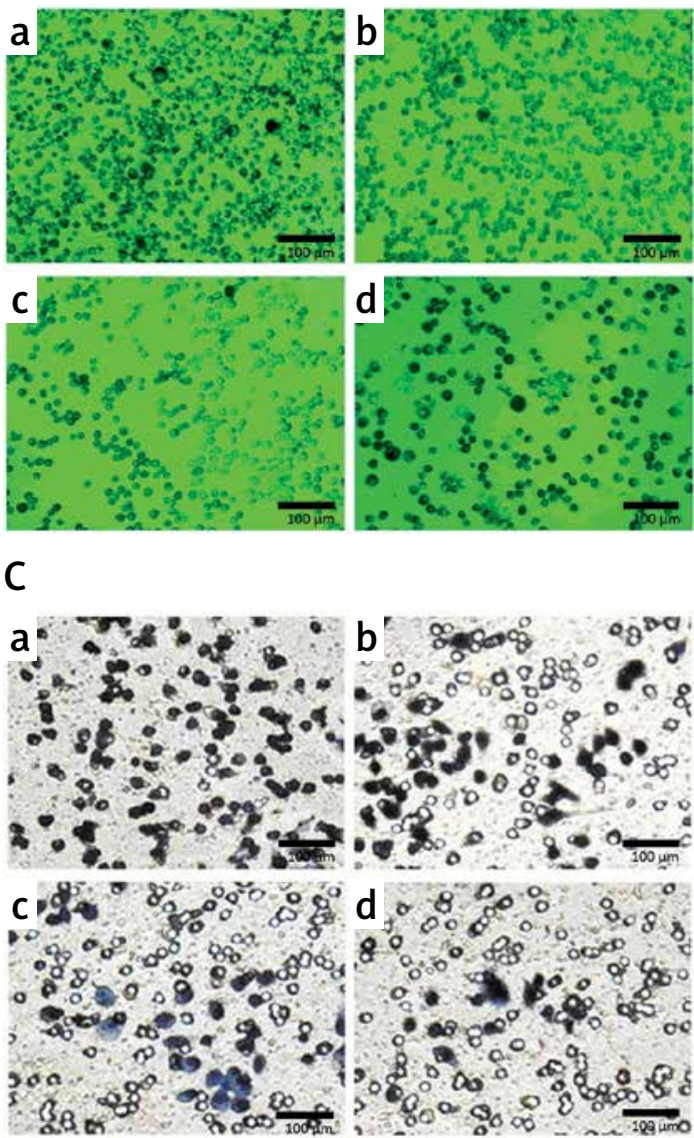

B

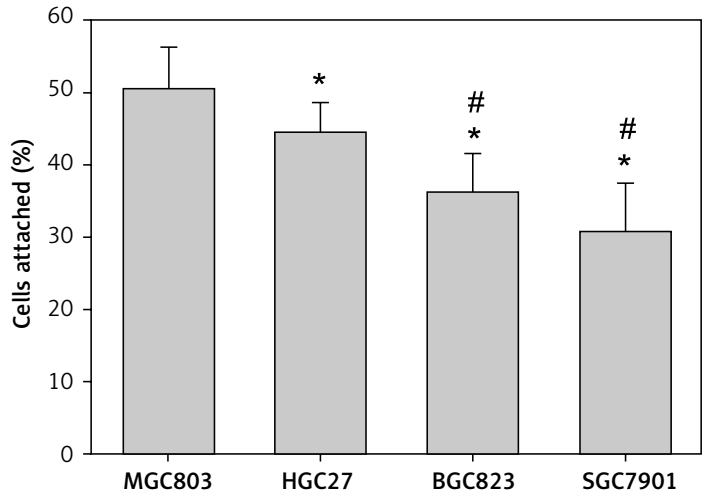

D

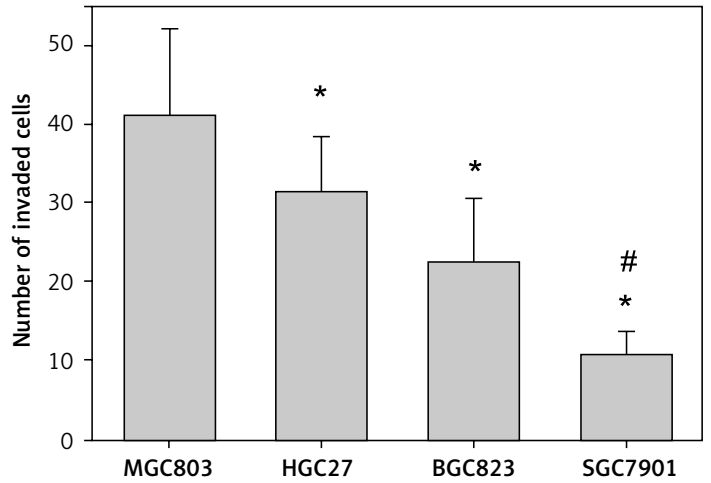

Figure 3. Adhesion and invasion ability of cancer cell lines. A - MGC803 (a), HGC27 (b), BGC823 (c) and SGC7901 (d) were tested for adhesion to a 96-well Matrigel-coated plate. B - Quantification of the adhesion ability (mean $\pm \mathrm{SD}) .{ }^{*} P<0.05$ compared with the MGC803. ${ }^{*} P<0.05$ compared with HGC27. C - Matrigel invasion assay: the representative histogram of invaded MGC803 (a), HGC27 (b), BGC823 (c) and SGC7901 (d). D - Number of invaded cancer cells is quantified. ${ }^{*} P<0.05$ compared with the MGC803, ${ }^{*} p<0.05$ compared with HGC27 or BGC823

creased by $26 \%, 42 \%, 48 \%$ and $52 \%$, respectively, compared with the vehicle-treated MGC803 cells (Figure $5 \mathrm{~B}$ ). The ability of adhesion and invasion of MGC803 was decreased by Endostar or Erbitux. The attached MGC803 cells treated with Endostar or Erbitux were decreased by $20 \%$ or $22 \%$, respectively, compared with the vehicle-treated MGC803 cells. Endostar and Erbitux decreased the invaded MGC803 cells through Matrigel by $22 \%$ and $39 \%$, respectively (Figure 6). The inhibition of Endostar and Erbitux on the mRNA expression of VEGF, EGF and their receptors in MGC803 cells contributed to the decrease of the proliferation, migration, adhesion, and invasion ability of MGC803 cells.

\section{Discussion}

EGF binds to receptors which are located on the cell membrane of various kinds of epithelial cells. EGF can stimulate the phosphorylation transduction pathway to regulate the proliferation and apoptosis of tumour cells. Many studies have revealed that the expression of EGF and its receptors was related to the ability of invasion and metastasis of gastric cancer cells, where overexpression signified short survival time and higher risk of recurrences for evaluation of prognosis [11, 12]. VEGF played a key role in the growth, invasion and metastasis of the tumour cells. VEGF binding receptors on the surface of vascular endothelial cells regulate angiogenesis of tumours and promote growth of tumours.

The results showed that lower survival was related to positive exfoliative cytology, lymphatic node metastasis, serosa-infiltrated and poorly differentiated gastric cancer. The biological properties of gastric cancer cells were related with prognosis. The mRNA expression of EGF and VEGF was significantly different between the exfoliative cytology positive cases and the negative cases. Two factors were confirmed to have a close correlation with abdominal cavity exfoliation of gastric cancer cells. As for serosa-infiltrated cases with cytology negative, overexpression of EGF and VEGF enhanced invasion and motility of the tumour cells to exfoliate into the abdominal cavity. 
A

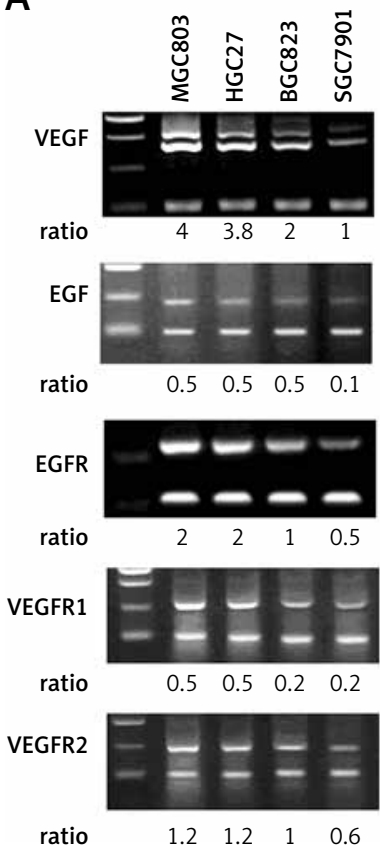

B

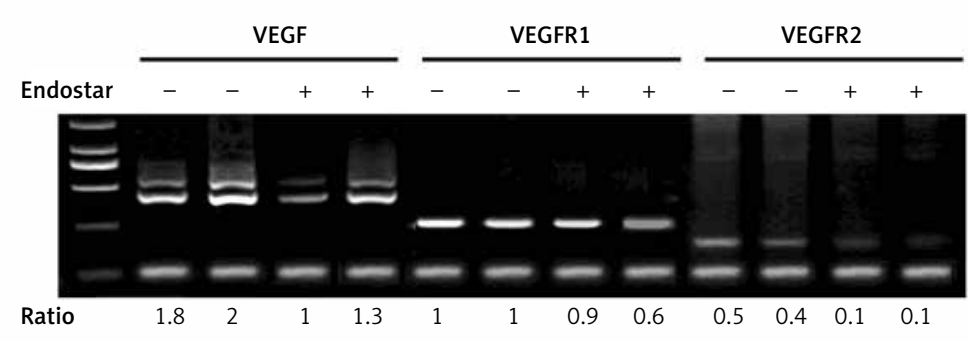

C

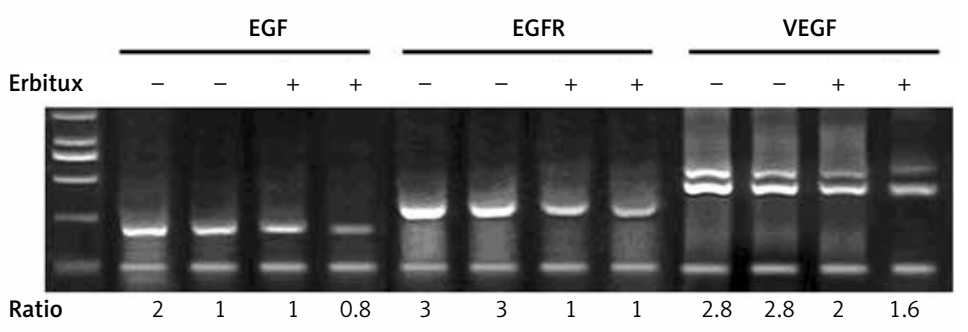

Figure 4. mRNA expression of VEGF and EGF in cancer cells with or without Endostar or Erbitux treatment. A - mRNA levels of VEGF, EGF, EGFR, VEGFR1 and VEGFR2 in colon cancer cells: MGC803, HGC27, BGC823 and SGC7901. B - VEGF, VEGFR1 and VEGFR2 in MGC803 cancer cells treated with Endostar. C - VEGF, EGFR and EGF in MGC803 cancer cells treated with Erbitux. Quantification of band density is shown. VEGF and EGF mRNA levels were normalized to the $\beta$-actin mRNA level

Contrarily, decreased secretion of EGF and VEGF inhibited proliferation of tumour cells, diminished nourishment and reduced metabolic capability of cancer cells. The opportunity of exfoliation of gastric cancer cells dropped accordingly. The mRNA levels of EGF, VEGF and their receptors in four gastric cancer cell lines showed that EGF and VEGF might regulate the biological properties of gastric cancer cells in an autocrine manner. Our study revealed that the properties compromised in order. This was in accordance with the expression of EGF, VEGF and their receptors in gastric cancer cells. Previous research has confirmed that the properties mentioned above were significantly correlated with peritoneal metastasis of gastric cancer [13-15]. Therefore, when EGF and VEGF were overexpressed in tumour cells, the function of transduction was stronger, which led to increased migration, invasion of gastric cancer cells and the likelihood of exfoliation. When exfoliated cells adhered to the peritoneum, EGF, VEGF and other factors increased the ability of proliferation, invasion and adhesion of cells. The tumour cells invaded the peritoneum easily, which led to micrangium genesis, provision of nutrition and implantation metastasis.
Vascular endostatin is hydrolysed from the carboxy terminal of extracellular matrix heparin sulfate glycoprotein (collagen XVIII). Its mechanism is still unclear. However, it is certain that it plays a key role in the process of tumourous angiogenesis. It can block activation of tyrosine phosphorylation, extracellular signal regulatory protein kinase, mitogen-activated protein kinase of KDR/ Flk-1 (receptor of VEGF) and signal transduction mediated by VEGF [16]. Endostar can inhibit activities of matrix metalloprotease-9 (MMP-9) precursor and MMP-13 precursor, inhibit ability of peroxidase and the breakage of MMP-2 precursor [17], inhibit migration of endothelial cells and movement of endothelial cells, and promote apoptosis of endothelial cells $[18,19]$. MGC803 was chosen as the experimental object as it showed the strongest expression of VEGF and other factors. When Endostar was added to MGC803, mRNA expression of VEGF and VEGFR was attenuated. It was likely that the blocked transduction of VEGF led to increased protein of free VEGF and free VEGFR, and negative feedback suppression of VEGF and VEGFR synthesis at the mRNA level.

Erbitux is an EGFR antagonist, and is also the only permitted new type of human/murine mono- 

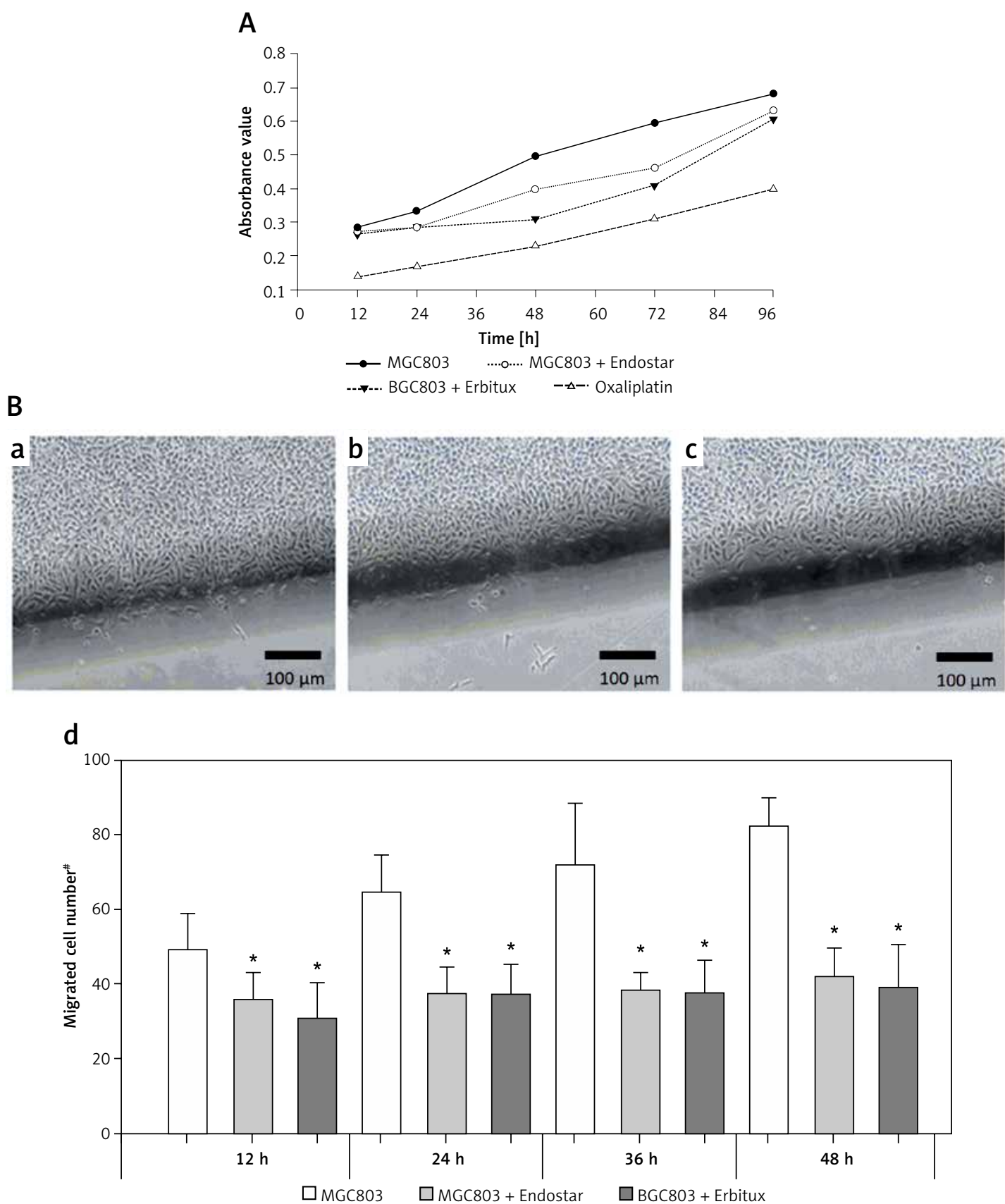

Figure 5. Inhibitory effect of Endostar and Erbitux on the growth and migration ability of MGC803 cancer cells. A - Growth curve of MGC803 treated $0.9 \% \mathrm{NaCl}$ as control or $1.75 \mu \mathrm{g} / \mathrm{ml}$ Endostar or Erbitux in $0.9 \% \mathrm{NaCl}$. B - Wound healing assay: representative micrograph of 36-h wound healing from MGC 803 treated with $0.9 \% \mathrm{NaCl}$ as control (a), $1.75 \mu \mathrm{g} / \mathrm{ml}$ Endostar (b) or Erbitux (c) in $0.9 \% \mathrm{NaCl}$ for $12 \mathrm{~h}$. Numbers of migrated cells were quantified at $12 \mathrm{~h}, 24 \mathrm{~h}, 36 \mathrm{~h}$ and $48 \mathrm{~h}($ mean \pm SD) (d)

${ }^{*} P<0.05$ compared with the MGC803 at the same time point.

clonal enqomphesis antibody of EGFR to be used in clinic. Erbitux can inhibit proliferation of cancer cells, which leads to apoptosis of cancer cells, and decreases production of MMP and VEGF [20, 21]. In addition, the expression of cyclin D1 and HIF would be down-regulated, which made cells arrested at the G1/G0 stage with inhibition of tumour angiogenesis [22, 23]. In this study, the mRNA expression of EGF and EGFR in MGC803 cells treated with Erbitux for $12 \mathrm{~h}$ was obviously reduced. Erbitux blocked EGF transduction and inhibited synthesis of EGF and EGFR at the mRNA level, which was the same as the mechanism of Endostar. The mRNA level of VEGF in cells was reduced, which indicated that EGF can induce mRNA expression of VEGF. Erbitux inhibition of both EGF and VEGF showed that Erbitux was more effective towards MGC803 cells than Endostar in vitro. 
A
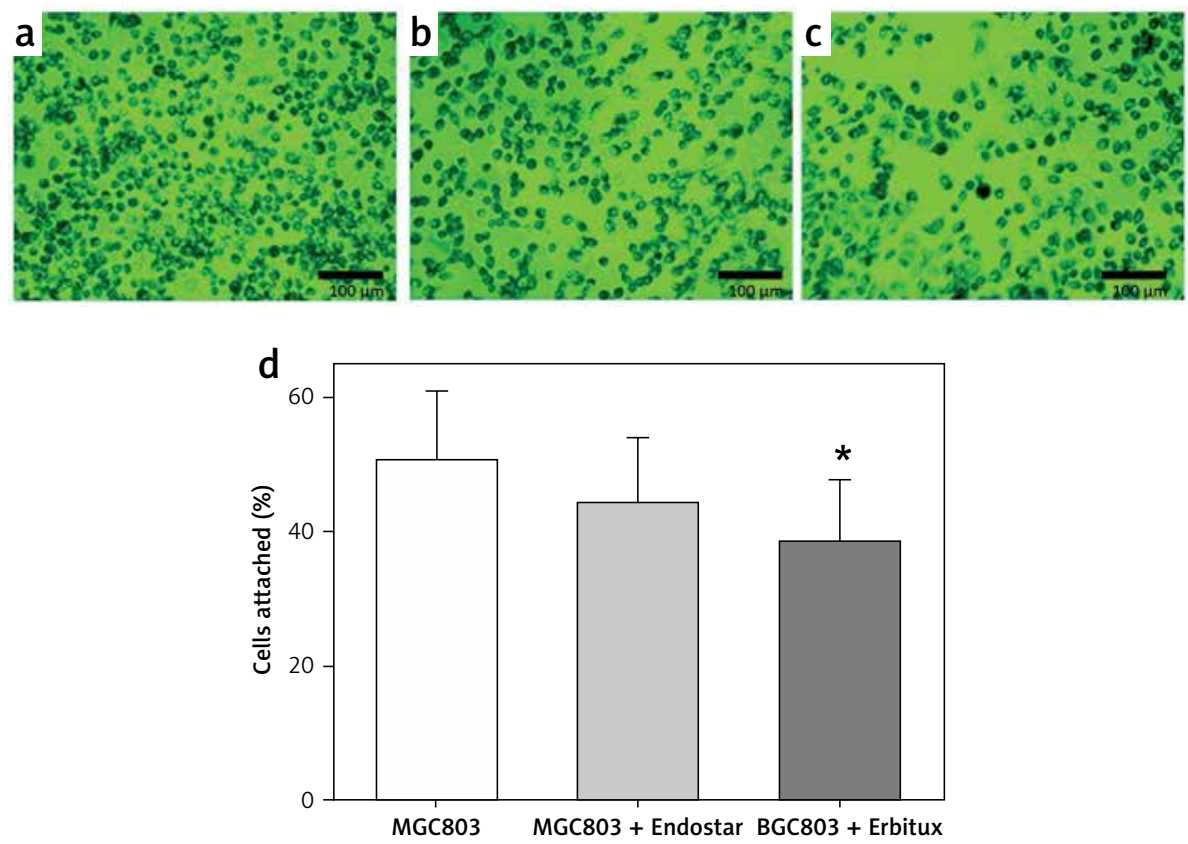

B
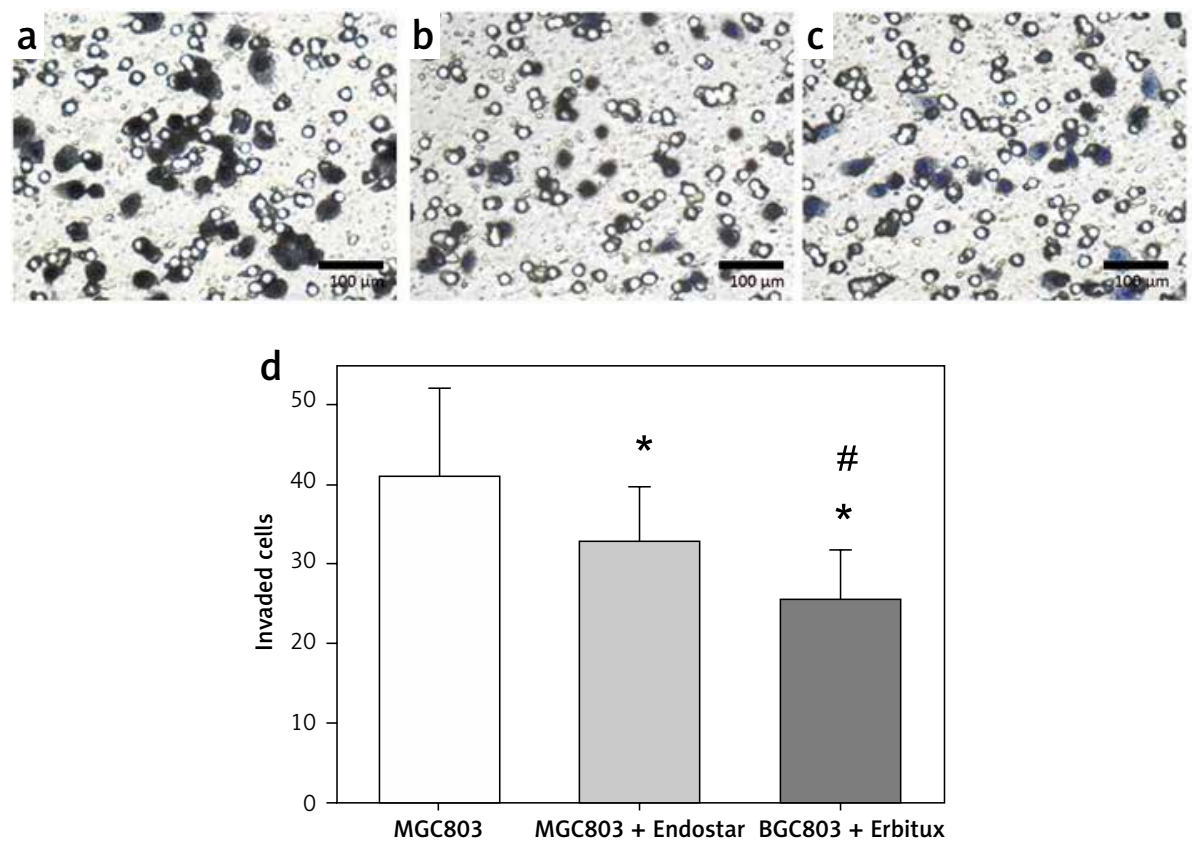

Figure 6. Inhibitory effect of Endostar and Erbitux on the adhesion and invasion ability of MGC803 cancer cells. A - MGC803 treated with $0.9 \% \mathrm{NaCl}$ as control (a) $1.75 \mu \mathrm{g} / \mathrm{ml}$ Endostar (b) or Erbitux (c) in $0.9 \% \mathrm{NaCl}$ for $12 \mathrm{~h}$ were tested for adhesion to a 96-well Matrigel-coated plate (d). Quantification of adhesion ability (mean \pm SD). ${ }^{*} P<0.05$ compared with MGC803. B - Matrigel invasion assay: representative histogram of invaded MGC803 (a), MGC803 treated with $1.75 \mu \mathrm{g} / \mathrm{ml}$ Endostar (b) or Erbitux (c) in $0.9 \% \mathrm{NaCl}$ for $12 \mathrm{~h}$ and number of invaded cancer cells is quantified in (d). ${ }^{*} P<0.05$ compared with the MGC803, ${ }^{*} p<0.05$ compared with the BGC823 treated with Endostar

Although oxaliplatin is more effective in the inhibition of MGC803 than Endostar and Erbitux, Endostar and Erbitux significantly inhibited the growth of MGC803 compared with vehicle-treated MGC803 cells, especially in $24 \mathrm{~h}$ or $72 \mathrm{~h}$ treatment.
A previous study reported that inhibiting the expression of VEGF and its receptor by down-regulating MMP could inhibit tumour angiogenesis and tumour metastasis [24]. Nevertheless, another study found that the stimulating effect of 
VEGF165 on expression and invasion of MMP-9 in human leukemic cells could be blocked by antibodies of VEGFR-1 and VEGFR-2 [25]. It was likely that reduced function of EGF and VEGF could lead to the changes of expression and activities of factors related to peritoneal metastasis such as MMP and $\beta$-integrin.

In conclusion, this study confirmed that the effects of EGF and VEGF were closely correlated with the biological properties of gastric cancer cells. Targeted inhibition of EGF and VEGF not only can lead to growth suppression of primary tumour but also can inhibit the invasion and metastasis of gastric cancer cells. The present study offered a theoretical foundation for wide application of molecular-targeted therapy in advanced gastric cancer.

\section{Conflict of interest}

The authors declare no conflict of interest.

\section{References}

1. Li S, Xue Y. Influence of volume of peritoneal lavage fluit on positive rate of peritoneal exfoliated gastric cancer cells. Chin J Gastrointest Surg 2015; 18: 131-4.

2. Kostić Z, Ćuk V, Bokun R, Ignjatović D, Ušaj-Knežević S, Ignjatović $M$. Detection of free cancer cells in peritoneal cavity in patients surgically treated for gastric adenocarcinoma. Vojnosanit Pregl 2006; 63: 349-56.

3. Kunisaki C, Makino H, Takagawa R, et al. Tumor diameter as a prognostic factor in patients with gastric cancer. Ann Surg Oncol 2008; 15: 1959-67.

4. De Manzoni G, Di Leo A, Tomezzoli A, et al. Prognostic value of peritoneal lavage cytology in gastric cancer. Chir Ital 2001; 54: 1-6.

5. Aoyagi K, Kouhuji K, Yano S, et al. VEGF significance in peritoneal recurrence from gastric cancer. Gastric Cancer 2005; 8: 155-63.

6. Kakeji Y, Koga T, Sumiyoshi Y, et al. Clinical significance of vascular endothelial growth factor expression in gastric cancer. J Exp Clin Cancer Res 2002; 21: 125-9.

7. Park DJ, Thomas NJ, Yoon C, Yoon SS. Vascular endothelial growth factor a inhibition in gastric cancer. Gastric Cancer 2015; 18: 33-42.

8. Vosseler S, Mirancea N, Bohlen P, Mueller MM, Fusenig NE. Angiogenesis inhibition by vascular endothelial growth factor receptor-2 blockade reduces stromal matrix metalloproteinase expression, normalizes stromal tissue, and reverts epithelial tumor phenotype in surface heterotransplants. Cancer Res 2005; 65: 1294-305.

9. Sun L, Ye HY, Zhang YH, Guan YS, Wu H. Epidermal growth factor receptor antibody plus recombinant human endostatin in treatment of hepatic metastases after remnant gastric cancer resection. World J Gastroenterol 2007; 13: 6115-8.

10. Yamashita H, Kitayama J, Shida D, et al. Differential expression of lysophosphatidic acid receptor-2 in intestinal and diffuse type gastric cancer. J Surg Oncol 2006; 93: 30-5.

11. Goto Y, Ando T, Goto H, Hamajima N. No association between EGF gene polymorphism and gastric cancer. Cancer Epidemiology Prevention Biomark 2005; 14: 2454-6.
12. Yasui W, Oue N, Aung PP, Matsumura S, Shutoh M, Nakayama H. Molecular-pathological prognostic factors of gastric cancer: a review. Gastric Cancer 2005; 8: 86-94.

13. Bai F, Guo X, Yang L, et al. Establishment and characterization of a high metastatic potential in the peritoneum for human gastric cancer by orthotopic tumor cell implantation. Dig Dis Sci 2007; 52: 1571-8.

14. Fujimoto D, Hirono Y, Goi T, Katayama K, Yamaguchi A. Prognostic value of protease-activated receptor-1 (PAR1) and matrix metalloproteinase-1 (MMP-1) in gastric cancer. Anticancer Res 2008; 28: 847-54.

15. Ishikawa M, Kitayama J, Yamauchi T, et al. Adiponectin inhibits the growth and peritoneal metastasis of gastric cancer through its specific membrane receptors AdipoR1 and AdipoR2. Cancer Sci 2007; 98: 1120-7.

16. Woo IS, Kim K, Jeon HM, et al. Pretreatment serum endostatin as a prognostic indicator in metastatic gastric carcinoma. Int J Cancer 2006; 119: 2901-6.

17. Hansma A, Broxterman H, Van Der Horst I, et al. Recombinant human endostatin administered as a 28 day continuous intravenous infusion, followed by daily subcutaneous injections: a phase I and pharmacokinetic study in patients with advanced cancer. Ann Oncol 2005; 16: 1695-701.

18. Ling Y, Yang Y, Lu N, et al. Endostar, a novel recombinant human endostatin, exerts antiangiogenic effect via blocking VEGF-induced tyrosine phosphorylation of KDR/Flk-1 of endothelial cells. Biochem Biophys Res Commun 2007; 361: 79-84.

19. Nie M, Fang G, Wang X, Su C, Oian O. Anti-tumor effect of gene-viral therapeutic system CNHK300-murine endostatin on nude mouse gastric cancer. Chin J Gastrointest Surg 2007; 10: 565-9.

20. Mendelsohn J, Baselga J. Status of epidermal growth factor receptor antagonists in the biology and treatment of cancer. J Clin Oncol 2003; 21: 2787-99.

21. Kim ES, Khuri FR, Herbst RS. Epidermal growth factor receptor biology (IMC-C225). Curr Opin Oncol 2001; 13: 506-13.

22. Huether A, Höpfner M, Baradari V, Schuppan D, Scherübl H. EGFR blockade by cetuximab alone or as combination therapy for growth control of hepatocellular cancer. Biochem Pharmacol 2005; 70: 1568-78.

23. Luwor RB, Lu Y, Li X, Mendelsohn J, Fan Z. The antiepidermal growth factor receptor monoclonal antibody cetuximab/C225 reduces hypoxia-inducible factor-1 alpha, leading to transcriptional inhibition of vascular endothelial growth factor expression. Oncogene 2005; 24: 4433-41.

24. Belotti D, Calcagno C, Garofalo A, et al. Vascular endothelial growth factor stimulates organ-specific host matrix metalloproteinase- 9 expression and ovarian cancer invasion. Mol Cancer Res 2008; 6: 525-34.

25. Dias S, Hattori K, Zhu Z, et al. Autocrine stimulation of VEGFR-2 activates human leukemic cell growth and migration. J Clin Invest 2000; 106: 511-21. 